\title{
オーストラリアのワイン法
}

高 橋 梯 二

\begin{abstract}
Iオーストラリアのワイン法の特色
オーストラリアのワイン法は, オーストラリアワイ ン及びブランデー公社法 (Australian Wine and Brandy Corporation Act 1980) (以下「ワイン法」と いう）及びオーストラリアワイン及びブランデー公社 規則 (Australian Wine and Brandy Corporation Regulations 1981）（以下「ワイン規則」という）から構 成されているが, また, オーストラリア・ニュージー ランド食品基準（Australia New Zealand Food Standards Code 1991）（以下「食品基準」という）も適用 になっている。
\end{abstract}

\section{1 ワイン法の対象及びワインの定義}

ワイン法は，ワイン及びブランデーを対象としてお り，ワインの定義は，「新鮮なブドウ若しくは新鮮な ブドウのみからつくられる産品の完全なあるいは部分 的な発酵によるアルコール飲料」と定義している。ま た，ワイン法にはアルコール分についての規定はない が, 食品基準に 8 度以上と定義されている。さらに,

食品基準には，「果実ワイン」，「野菜ワイン」という 用語もあり, これらも「ワイン」の用語を用いること ができる。

なお,「新鮮なブドウ」とは, 水分 $60 \%$ 以上のブド ウと規定されている。

\section{2 ワイン法の目的及びオーストラリアワイン公 社の役割}

ワインとブランデーの輸出の振興と管理を第一の目 的とし, 併せて, これらの産品の消費の拡大も目的と
している。この目的達成のため，オーストラリアワイ ン公社 (以下「公社」という」を設立し, ワイン法の 目的のための具体的な施策の推進に関する権限を全面 的に公社に付与している。従って, 公社は法令には従 わなければならないが, 具体的な施策の運営に当たつ ては原則として政府からの指示は受けないことになっ ている。

\section{3 適正ラベル計画 （Label integrity program）}

この計画は, オーストラリアで生産されるワインに おけるヴィンテッジ, 品種及び地理的表示についての ワインの表示が真実であり，真実であることの信頼性 を高めることを目的としている。その内容は, ワイン 関係業者に対する記録義務（トレーサビリティ義務）, 公社が任命する検査官の立入検査を含む検査, 公社の 関係業者に対する資料要求権限である。ただし，この 計画はオーストラリアのワインのみに適用され, 公社 が全面的に管理している。

\section{4 表示に関する規制}

オーストラリア及び海外の地理的表示, 伝統的表現 などの保護についてはワイン法において規定し，オー ストラリアのワインについての品種表示, ヴィンテッ ジ表示, 地理的表示などワインに特有の表示はワイン 規則で規定している。アルコール度の表示などその他 の食品と共通する表示基準は食品基準によっており, ワインの表示基準はいくつかの法令で規制されている。 なお, オーストラリアの法令には,「ジェネリッ ク・ワイン」,「ヴァライエッタル・ワイン」,「ヴィン テッジ・ワイン」の分類はない（アメリカのワイン法

Australian Wine law

Teiji Takahashi (Lecturer, Graduate School of Agricultural Sciences, Tokyo University) 
にはこれらの分類の規定がある)。

\section{（1）地理的表示や伝統的表現の保護}

これは, WTOの TRIPS 協定（知的所有権の貿易 関連の側面に関する協定 1994）やEUとのワイン貿 易に関する協定など国際協定に基づく義務の履行を定 めたものであり,「誤った表示」と「誤認を招く表 示」に分類し, 違反に対しては 2 年の禁固という重い 罰則を適用しており, これは貿易重視の現れと思われ る。

\section{（2）ブドウ品種，ヴィンテッジ及び地理的表示の表示}

他の国の表示基準とほぼ同じょうに，85\%，95\%以 上などの表示できる容量割合を定めている。優良誤認 を招きやすい表示，つまり，割合の少ない優良品種や ヴィンテッジを表示することを禁止する規定が設けら れている。

\section{（3）EU との協定に基づく表示規制}

オーストラリアのワインが EU に輸出される場合, 「White Burgundy」などの EUの産地名の使用, 「Hermitage」などの使用が問題とされ，オーストラ リアは長年にわたって $\mathrm{EU}$ と交渉を行い，EUへの輸 出がスムースに行えるように努力してきた。最新の $\mathrm{EU}$ との協定は 2008 年に締結され，これに基づくオ ーストラリアの義務をワイン規則によって規定してい る。

$\mathrm{EU}$ の登録された地理的表示名は, EU との協定締 結後 1 年間の猶予期間をもってオーストラリアのワイ ンには使用できないこととした（「Tokay」のみは 10 年間の猶予期間)。また,「シャトー」などの $\mathrm{EU} の$ 登 録された伝統的表現はオーストラリアのワインに使用 できないこととしたが, 商標登録等によって以前から 使用されていた伝統的表現は継続して使用できること としている。

なお， $\mathrm{EU} は, \mathrm{EU} の$ 登録された地理的表示名とブ ドウの品種名が競合する場合（品種名に地理的表示名 が含まれる場合, 品種名と地理的表示名が同一の場合 など）は，原則としてその品種名の表示を禁止してお り, 例外として表示できる品種は, 品種ごと, $\mathrm{EU}$ 加 盟国ごと，第 3 国ごとに定められている。EU との協
定によってオーストラリアのワインが使用できるこれ らの品種は次のとおりワイン規則に定められている。

Alicante Bouchet, Barbera, Carignane, Chardonnay, Orange Muscat, Pinot Chardonnay, Rhine Riesling, Trebiano

これによると，日本が EU にワインを輸出する場合， 「ミューラトウルガウ」,「バルベラ」などの EU の地 理的表示名と競合する品種名は表示できないと解釈す ることができ，また，EUの地理的表示の保護を協定 によって約束しているアメリカやオーストラリアに輸 出する場合も表示できない恐机もある。

\section{（4）外国のワインとの混合の場合の表示}

ワインが複数の国で栽培されたブドウからつくられ ている場合は，そのワインの表示において各国を原産 とするワインの割合を示さなければならない。これに よるとワインをブレンドした場合はもとより, 輸入果 汁によって製造したワインもその国名とブレンド割合 を表示しなければならないと解釈される。この基準は 輸入ワインについても適用となる。

\section{（5）食品基準による義務表示}

ワイン法やワイン規則は, 表示に関しては, 品種, ヴィンテッジ, 地理的表示, 伝統的表現などワインに 特有の事項しか扱っておらず，アルコール容量表示, 二酸化硫黄含有表示などの義務表示については食品基 準で定めている。食品基準は輸入ワインについても適 用となる。これらの義務表示について他の国と異なる ものは，(1)アレルギー表示の一環として，卵や牛乳を 清澄のために使用した場合は,「卵使用」や「牛乳使 用」と表示しなければならないこと, (2) $10 \mathrm{~g}$ の純ア ルコールを基準（1drink）とする基準飲酒量（standard drink labeling) を表示しなければならないこと， (3)ガラスびん以外の容器を使用し 2 年以内に消費期限 を迎えるワインは賞味期限を表示しなければならない ことなどである。

\section{5 オーストラリア地理的表示}

オーストラリアがEUにワインを輸出する場合, 産 地表示については EU の規則に合致しているかどうか 
などにつき絶えず問題になっていたことから，EUは オーストラリアに扔いても産地表示基準を法律におい て制度化することを勧告し，地理的表示制度ができれ ばオーストラリアのワインの産地表示を EU市場にお いても認め, 保護することとした。これに基づき 1994 年に「オーストラリア地理的表示」が導入された。 地理的表示は, ワイン製造業者又はブドウ栽培者若 しはそれらの代表的な団体等からの申請若しくは地理 的表示委員会（以下委員会という）の発案によって委 員会が決定できることになっている。決定に当たって は公告をしなければならず，特に商標権者の異議を確 認しなければならない。異議があった場合商標登録管 理者はその見解を提出しなければならない。この見解 に異議がある場合は連邦裁判所の決定を求めることに なっている。法律では, 地理的表示と商標との調整手 続きについて定め, さらに, 規則においてはより詳細 な調整手続きが定められている。この調整規定をみる と地理的表示と商標との間では先願主義ということで もないと理解される。

なお, オーストラリアのこの地理的表示は, 委員会 により決定登録された地域内のブドウを原則 $85 \%$ 以 上使用していれば，その地理的表示のワインへの表示 が可能であり, 品種規制, 単収規制などのその他の基 準は定められておらず，EUの地理的表示制度とは内 容に执いて大きく異なっている。従って, アメリカの 原産地呼称 (AVA 制度等) と同様オーストラリアの 地理的表示もいわゆる産品の表示基準にすぎず, TRIPS 協定で定められた知的所有権としての地理的 表示ではないとの学者等の意見がある。

\section{6 輸出管理}

輸出の振興と管理を重視するオーストラリアでは, ワイン規則により，公社による厳格な輸出管理を行う ことを定めている。まず輸出に当たっては輸出免許が 必要であり, 具体的な輸出に当たっては, 輸出許可証 (輸出証明書) が必要である。公社は輸出業者に指示 を与えることができ, 輸出相手先などについての輸出 量を指定することができる。さらに必要な資料の提供 を求めることができる。

\section{7 ワイン製造基準}

ワインの製造基準は, 食品基準によって定められて いる。この食品基準は輸入ワインにも適用される。し かし, 国際協定によって輸出国の製造基準が合意され ている場合は輸入ワインについてはその基準が適用さ れる。

なお，製造基準によれば補糖は認められていない。

\section{II オーストラリアワイン及び ブランデー公社法の概訳 \\ (Australian Wine and Brandy Corporation Act 1980, 2011 改訂)}

\section{第 1 部 序}

\section{3 目的}

この法律の目的は,

(a) ブドウ産品の輸出を促進し，管理すること。

（b）ブドウ産品の輸出後の販売と流通を促進し, 管 理すること。

(c) オーストラリアの州間でのブドウ産品の取引を促 進すること。

（d）ブドウ産品の生産の改良及び消費を促進すること。

（e）ワイン貿易に関する協定その他の国際合意をオー ストラリアが遵守できるようにすること。

\section{4 定義（主なもののみを取り上げた）}

「新鮮なブドウ」とは, 水分 $60 \%$ 以上のブドウをい う。

「ブドウ産品」とは, 次のものをいう。

（a）オーストラリアに拈いて指定産品からつくられ るワイン

（b）オーストラリアに拈いて上記ワインから蒸留 されるブランデー

（c）オーストラリアに扔いて指定産品からつくられ るグレープスピリッッであって, 酒精強化ワイ ン又はブランデーの製造に適するもの

（d）ワイン法の目的のためブドウ産品に関する規 則に定められた産品 
「指定産品」とは，次のものをいう。
(a) 新鮮なブドウ
(b) 乾燥ブドウ
（c）ブドウ果汁（濃縮果汁を含む）

「ワイン」とは, 新鮮なブドウ若しくは新鮮なブド ウのみによってつくられる産品の完全なあるいは部 分的な発酵によるアルコール飲料をいう。また，本 法の目的のためワイン規則によって定められるブド ウ産品を含む。

「ワイン産品（wine goods）」とは，次のものをいう。 (a) ワイン又は,

(b) ワインの生産のために使用されるブドウある いはブドウ抽出物

「ヴィンテッジ」とは，次のものをいう。

(a) ブドウに関しては，ブドウが収穫された年

（b）ワイン又はブドウ抽出物については，そのワ イン又はブドウ抽出物が製造又は取得されたブ ドウが収穫された年

\section{第 2 部 ワインオーストラリア公社}

7 ワインオーストラリア公社（以下「公社」とい う）の役割

（a）オーストラリアからのブドウ産品の輸出の促進と 管理

（b）オーストラリア及び海外におけるブドウ産品の 消費及び販売の促進

（c）オーストラリアにおけるブドウ産品の生産の改良

（d）ブドウ産品の販売に関する研究の実施，調整及 び支援

（e）ワイン法又はワイン規則によって公社に与えられ たブドウ産品に関するその他の役割

注：公社の組織等に関する第 3 部から第 5 部までは 省略した。

\section{第 $5 A$ 部 公社の業務}

第 $31 \mathrm{~K}$ 条 公社及び地理的表示委員会に対する指示

（1）本条に定められている場合及び連邦機関及び企業 法 1997 (Commonwealth Authorities and Com- panies Act 1997）において定められている場合 を除き，公社は連邦政府からの指示（命令）の対 象とならない。

（2）ただし，大臣が必要と判断する場合は，公社に対 して指示することができる。

\section{第 6A 部 適正ラベル計画（Label integrity program）}

\section{第 1 章 序}

第 39A 条この部の目的

この部の目的は, オーストラリアで生産されるワイ ンのヴィンテッジ，ブドウの品種又は地理的表示につ いてのワインになされる表示又はその他の商業目的で なされる表示が真実であり, 真実であることの評価を 得ることを支援することによって，ワイン法の目的を 達成することである。

第 39C 条この部が適用となる者

（1）この部は，（3）の場合を除き次の者が適用となる。

(a) ワイン産品であるブドウを栽培する者

（b）ワイン産品を生産する者

（c）ワイン産品を供給するか受け取る者（卸売又は 小売としてワイン産品を販売する者若しくは輸 入する者を含む)

（d）ワイン規則により指定される者

（e）（a）〜（d）に揭げられた者のためにワイン産 品を所有する代理人

（2）（1）（d）の目的のため, ワイン規則によって次 を定めることができる。

(a)この部が適用となる者の種類

（b）この部が特定された者の種類に適用される状 況

（3）（1）の規定にかかわらず，次の者にはこの部が適 用にならないことをワイン規則により定めること ができる。

(a) 特定された者の種類

（b）特定の状況における特定された者又は者の種 類

（4）この部はワイン産品がオーストラリアを原産とす 
る場合においてのみ適用となる。

\section{第 2 章 表示に関連した記録}

第 $39 \mathrm{~F}$ 条 記録者の義務

（1）この部が適用となる記録者（record keeper）は, ワイン産品に関する次の詳細を示す記録を書面に

より保持しなければならない。

（a）記録者の特定（identity）

（b）記録に関係するワイン産品の種類

（c）ワイン産品を受領した日

（d）受領したワイン産品を供給した者の特定

(e）受領したワイン産品の量

（f）受領したワイン産品のヴィンテッジ，品種及び 地理的表示

（g）次の事項について記録者が変更を行うか影響 を与えた場合，その記録者がとった措置

（ア）ヴィンテッジ, 品種, 地理的表示

（イ）ワイン産品が保管されているタンク，その 他の場所又は物

（ウ）上記のタンク，場所又は物に保管されてい るワイン産品の量

（h）記録者がワイン産品を供給した日

(i) ワイン産品の供給先の者の特定

（j）供給したワイン産品の量

(k）供給したワイン産品のヴィンテッジ, 品種及 び地理的表示

（1）規則によって定められたワイン産品に関するそ の他の事項

（2）記録は 7 年間保存されなければならない。

第 39G 条 記録が求められない事項

（1）ブドウ栽培者は，第 $39 \mathrm{~F}$ 条（1）（c）〜（f）まで を示す記録を保持することは要求されない。

（2）直接販売されるワイン産品については，第 $39 \mathrm{~F}$ 条（1）（h）（k）までの事項に関する記録は 要求されない。

第 $39 \mathrm{H}$ 条 記録が必要な詳細事項

注：ブドウ品種，記録者・供給元・供給先など，製 造 (省略)

ブレンド
（4）複数のヴィンテッジ, 品種, 地理的表示のワイン の場合，次の詳細が記録されなければならない。

(a) ブレンドされるワインのブレンドの割合

(b) ブレンドされた各ワインに扔けるヴィンテッジ, 品種, 地理的表示

第 39J 条 違反の場合の罰則

記録を保持しなかった場合, 誤ったあるいは誤認さ れる記録を行った場合は 2 年の禁固（imprisonment）

第 39ZAA 条 公社の記録の要求

公社は，記録を保持している者に対して書面によっ て次の事項を求めることができる。

（a）供給業者（ラベルに供給業者として記載されて いる者）に対して，記録に関連した特定の情報 を提供すること。

（b）ワイン法による記録を保持していると公社が 信じる者に対してその記録を提供すること。

\section{第 3 章 検查}

第 39ZA 条 検査官の任命

公社を代表して主要職員（principal employee）は, 検査官を任命できる。

検査官の適格者は

(a) 公社職員

（b）連邦又は連邦当局の職員

（c）長が合意した場合，州又は準州の職員

（d）長が合意した場合，地方自治体の職員

第 39ZC 条 検査官の権限

検査官は，表示に関する法律が遵守されているかど うかを確認するため，身分証明書作成後，ワイン施設 の管理者の同意を得て，その場所において検査を実施 することができる。

第 39ZD 条 検査令状

（1）検査官は，特定の場所における検査の令状（warrant）を判事（magistrate）に申請することがで きる（注 強制的に検查する場合）。 
第 39ZE 条 同意を得て行使する検查官の権限

(1) 立ち入り検査

表示に関する違反の証拠を得るための合理的な理 由がある場合, 検査官は特定の場所における立ち 入り検査を行うことができる。この場合当該場所 の管理者の同意を得ることが必要である。

(2) 証拠物件の差し押え

表示に対する違反の証拠を得るための合理的な理 由がある場合, 検查官は物件を差し押える (seize）ことができる。

第 $39 Z \mathrm{H}$ 条 質問及び文書作成の要求権限

（1）立ち入り検査を行った検査官は，その場所の者に 対して次を要求できる。

(a) 質問に対する回答

（b）検証するための文書の作成

（3）実施しない者に対しては 30 penalty units が課さ れる。

\section{第 6B 部 地理的表示及びその他の用語の保護}

第 1 章 序

第 $40 \mathrm{~A}$ 条この部の目的

この部の目的は, 次のためにワインの販売, 輸出及 び輸入を規制することである。

（a）オーストラリアがワイン貿易に関する合意及び その他の国際的合意の義務を実行するため。

（b）これ以外の目的で議会が法律を作成するため。

\section{第 2 章 販売, 輸出又は輸入に関する規定}

第 40C 条 誤った表示によるワインの販売, 輸出又 は輸入

誤った表示によるワインの販売, 輸出又は輸入を行 つた者は, 禁固 2 年

第 40D 条 誤った表示

次の場合は, 誤った表示となる。

(a) 国の名前が含まれており，ワインがその国を原 産としていない場合

（b）登録された地理的表示が含まれており，それが，
当該地理的表示に関係する国，地域，地方を原 産としていない場合

（c）登録された伝統的表現を含んでおり，ワインが その登録された表現と関係ない場合，あるいは 登録された表現に関係するワインの種類でない 場合

第 40DB 条 伝統的表現を含む場合で誤った表示とみ なされない場合

（1）ワインがオーストラリア原産であって, 品質用語 が登録された伝統的表現でもある場合であって, ワインがその用語に関係するものである場合は, その品質用語が含まれていても誤った表示とはな らない。

注：登録されたオーストラリアの品質用語 クリーム (cream), クラステッド（クラスティ ング） (crusted/crusting), ルビー (ruby), ソ レラ (solera), トーニー (tawny), ヴィンテッ ジ (vintage)

いずれも酒精強化ワインに適用される品質用語で ある。

（2）ワイン貿易協定を締結していない国を原産とする ワインの場合，誤認を招かず，工業所有権に関す るパリ条約 1883 年第 10 条 bis に規定する不公正 な競争とならない場合には，登録された伝統的表 現が含まれていても誤った表示とはならない。

（3）商標が含まれる場合であって，その商標が登録さ れた伝統的表現を含む場合，その商標が伝統的表 現の保護以前に登録されていたか使用されていた 場合は，その商標が含まれていても誤った表示と はならない。

（4）ビジネスの名前が含まれている場合であって，そ れが伝統的な表現から構成されている場合, ビジ ネスの名前が伝統的表現の保護以前に州の法律に よって登録されていた場合は, このビジネスの名 前が含まれていても誤った表示とはならない。

第 $40 \mathrm{E}$ 条 誤認を招く表示のワインの販売, 輸出又 は輸入

誤認を招く表示によるワインの販売，輸出又は輸入 
を行った者は, 禁固 2 年

第 $40 \mathrm{~F}$ 条 誤認を招く表示

（1）地理的表示又は伝統的表示が含まれる場合であっ て, 次の場合は誤認を招く表示となる。

（a）地理的表示がワインの原産とする国，地域また は地方について誤認を招くような方法で表示さ れている場合。

（b）伝統的表現についてその表現の登録と関連す る国，地域又は地方を原産とするワインである と, あるいは表現の登録と関連する分類のワイ ンであると誤認させるような方法で表示される 場合。

（2）登録された地理的表示又は伝統的表現について, それらに「type 」,「style」「imitation」,「 method」あるいはそれらと類似する表現が伴ってい ても, その地理的表示の産地あるいは伝統的表現 が認められている産地のワインでない場合。

（3）登録された地理的表示又は伝統的表現と類似した （resemble）表現を含み, 地理的表示又は伝統的 表現の登録と関係する国, 地域又は地方のワイン であると誤認を招くような方法で表示されている 場合。

（4）ワインを生産, 販売, 輸出又は輸入している個人 の名前であって, その名前あるいは住所がワイン の原産である国，地域又は地方であるかのように 誤認を招くよう使われている場合。

第 $40 \mathrm{FB}$ 条 伝統的表現を含む表示で誤認を招かない 表示

（1）ワインがオーストラリア原産であって, 品質用語 が登録された伝統的表現でもある場合であって,

ワインがその用語に関係する種類のものである場 合は，その品質用語が含まれていても誤認を招く 表示とはならない。

（2）商標が含まれる場合であって，その商標が登録さ れた伝統的表現を含む場合，その商標が伝統的表 現の保護以前に登録されていたか使用されていた 場合は，その商標が含まれていても誤認を招く表 示とはならない。

（3）ビジネスの名前が含まれている場合であって，そ れが伝統的な表現から構成されている場合, ビジ
ネスの名前が伝統的表現の保護以前に州の法律に よって登録されていた場合は, このビジネスの名 前が含まれていても誤認を招く表示とはならない。

第 $40 \mathrm{G}$ 条 登録された使用の条件に反する表示のワ インの販売, 輸出又は輸入

登録された地理的表示, 伝統的表現, 品質用語又は 追加的な用語の表示に扔いて, 登録された使用の条件 に合致していない表示を行った販売, 輸出又は輸入を した者は, 禁固 1 年

第 $40 \mathrm{M}$ 条 輸入ワインへの国内食品基準の適用

ワインに適用となる醸造行為, 加工又は組成に適用 される国内基準の要求事項は, 海外を原産とするワイ ンについても適用される。ただし，(1A）又は（1B） の場合は, これらの要求事項が適用される。

（1A）ワインの貿易に関する合意（agreement）で定 められた醉造行為, 加工又は組成に関する基準

（1B）海外のワインとの関係において規則によって定 められる醇造行為, 加工又は組成に関する要求事 項

\section{第3 章 地理的表示委員会 (Geographical Indica- tions Committee）の設立及び機能}

第 $40 \mathrm{~N}$ 条 地理的表示員会の設立

地理的表示委員会 (以下「委員会」という) が設立 される。

第 $40 \mathrm{Q}$ 条 地理的表示を決定する委員会の役割 委員会は,

（a）ワインに関するオーストラリアの地理的表示の 申請を取り扱う。

（b）オーストラリアの地理的表示の決定（determination）を行う.

（c）オーストラリアの地理的表示の取り消しの決定 を行う。

（d）規則によって与えられたその他の機能を実施 する。 


\section{第 4 章オーストラリア地理的表示}

第 40Q 条 地理的表示を決定する委員会の権限

委員会は，自らの発案で，あるいは申請によりオー ストラリアの地域に関する地理的表示を決定すること ができる。

第 $40 R$ 条 地理的表示の申請

次の者は, 委員会に対して地理的表示の決定につい て申請することができる。

（a）大臣が認めたワイン製造者の全国的組織

（b）大臣が認めたワイン用ブドウ生産者の全国的 組織

（c）州又は準州においてワイン製造者を代表する組 織

（d）州又は準州においてワイン用ブドウ生産者を 代表する組織

(e) ワイン製造者

(f) ワイン用ブドウ生産者

第 40RA 条 地理的表示提案に関する公告（notice）

（1）委員会の長は，申請された地理的表示又は自らの 発案による地理的表示について公告しなければな らない。

（2）当該公告においては，

(a) 提案された地理的表示を示し,

（b）異議があるものに対して商標登録管理者（Registrar of Trade Marks）にそれを提出するよう 促さなければならない。

(c) 異議は, 公告から 1 力月以内で提出されるよう 求めなければならない。

第 40RC 条 異議に対する考慮

（1）商標登録管理者が，異議を受領した時は，委員会 に対して通知しなければならない。

（2）異議が委員会に通知された後，商標登録管理者は, 当該異議に理由があるのかないのか決定しなけれ ばならない。

（3）商標登録管理者は, 当該意義に理由があると決定 した場合においても，提案された地理的表示が決 定されるべき合理的な状況があると認めるときは, 商標登録管理者は勧告をしなければならない。
（4）（3）の合理的な状況を決定するに当たり，商標登 録管理者はオーストラリアの国際的な義務を尊重 しなければならない。

第 40RD 条 決定についての公告

（1）商標登録管理者は，決定をした時は，次の者に対 してその決定及び勧告を通知しなければならない。

（a）地理的表示を提案した者

（b）提案された地理的表示に異議を申し出た者

(c) 委員会

（2）委員会の長は，商標登録管理者から上記の通知を 受けた時は，次を公告しなければならない。

(a) 提案された地理的表示

（b）商標登録管理者の決定があったこと

(c) 商標登録管理者の決定の条件及び勧告

第 40RE 条 異議の理由が存在しなくなったことの決 定

（1）異議について理由があるとの決定がなされた後に， ある者が状況の変化により, 異議の理由がなくな ったことを商標登録管理者に書面により提出した 時は，商標登録管理者は，異議の理由が存在しな くなったことの決定をすることができる。

第 $40 \mathrm{RF}$ 控訴 (Appeals)

商標登録管理者の決定に対する控訴は，連邦裁判所 に対して行うことができる。

第 40SA 条 地理的表示の決定の時期

（1）異議の提出があった場合において，委員会は本条 に定められた場合においてのみ，地理的表示を決 定することができる。

（2）異議の理由が示されなかった場合は，委員会は地 理的表示の決定ができる。

（3）異議の理由が示されても, 異議を申し出た者が地 理的表示の決定に合意した場合は，委員会は地理 的表示の決定ができる。

（4）異議の理由が示されても，商標管理者が勧告をし た場合は，委員会は地理的表示の決定ができる。 


\section{第 5 章 保護地理的表示及びその他の用語の登録}

第 40ZA 条及び第 40ZB 条

登録管理者（Registrar）は，保護地理的表示及び その他の用語の登録を管理する。

第 40ZD 条 登録の内容

登録は次の 4 部で構成される。

(a) 第 1 部

（i ）オーストラリアの地理的表示及びその適用 に当たっての条件

（ii）海外の地理的表示及びその適用に当たって の条件

(b) 第 2 部

海外の伝統的表現及びその適用に当たっての条件

(c) 第 3 部

オーストラリアのワインに関する品質用語 (quality wine term）及びその適用の条件

(d) 第 4 部

ワインに関するその他の用語及びその適用に関す る条件

注 : 外国からの地理的表示の申請と登録及び地理的 表示登録の取り消しに関しては省略した。

\section{III オーストラリアワインブランデー公社規則 1981 の概訳}

(Australian Wine and Brandy Corporation Regulations 1981，2010 年改訂)

\section{第 2 部 輸出管理}

第 5 条 輸出免許の供与

（1）公社は，申請に基づき，要求事項を考慮し，申請 者に対しブドウ産品のオーストラリアからの輸出 免許（license）を付与することができる。

（2）免許の有効期間は 3 年以内で免許に特定された期 間有効である。また更新可能である。

第 6 条 輸出の条件

（1）以下を満たしていなければ, ブドウ産品の輸出は 禁止される。 （a）輸出者が免許を所有していること。

（b）公社が購入者を認めていること（approved）。

(c) 産品が免許所有者に与えた公社の指示に従って いること。

（d）産品が商品として売れるものであること。

（e）免許所有者が公社に対して産品の見本及びラベ ルを提供していること

（f）公社がその産品に対して輸出許可書（certificate）を与えていること。

（3）ブドウ産品の輸出量が別に定める少量の場合は, 上記（1）は適用されない。

第 $6 \mathrm{~A}$ 条 輸出の条件 食品基準

（1）ブドウ産品がオーストラリア・ニュージーランド 食品基準（食品基準）を満たしていなければ輸出 は禁止される。

（2）ただし，公社が承認した場合は，特定の事項につ いて，輸入国の条件に合致し，かつ，食品基準を 満たさないことがオーストラリアのブドウ産品の 評価を下げない場合において，上記食品基準を満 たしていなくても輸出が可能である。

（3）承認は，非準拠の事項を指摘し，他のいかなる関 連基準にも準拠しなければならないことを述べ, 書面によって輸出者に行われる。

第 7 条 輸出許可証 (Certificate)

（1）免許の所有者はブドウ産品の輸出について公社に 対し輸出許可証の発給を通知して申請できる。

（3）この通知は，輸出される10日前までになされな ければならない。

（3A）公社は，通知を考慮するに当たって，免許の所 有者に対しブドウ産品の表示が, 連邦, 州の法律 に適合しているかどうかに関する資料の提出を求 めることができる。

第 8 条 公社の権限

公社は，免許の所有者に対して輸出できるブドウ産 品の量について

（a）輸出先を特定することなく，あるいは

（b）輸出先国を特定して，あるいは

（c）輸出先の者，代理人などを特定して, 
指示することができる。

第 11 条 公社の情報提供要求

（1）公社から書面によって, ブドウ産品の販売, 廃棄, 輸出に関する情報を特定して要求された場合は, 定められた期間内にその情報を公社に提出しなけ ればならない。

\section{第 3 部 違反条項の例外}

第 13 条 地理的表示及び伝統的表現

（1）表 1 に示す地理的表示又は伝統的表現の使用は, 協定（2008 年の EU とのワイン貿易に関する協 定）発効後 12 ヶ月間は, 認められる。

表 1

Amontillado, Auslese, Burgundy, Chablis, Champagne, Claret, Fino, Graves, Manzanilla, Marsala, Moselle, Oloroso, Port, Sauternes Sherry, Spallese, White burgundy

（2）地理的表示「Tokay」の用語の使用は，協定発効 後 10 年間は, 認められる。

第 14 条 Hermitage のワイン

ワインの表示に抒ける「Hermitage」の名称の使用 は, 次の場合には協定発効後 12 力月の間は認められ る。

(a)この名称がブドウ品種「Shiraz」の同義語とし て使用される場合で

（b）ワインがオーストラリアを原産とし，

(c) ワインが $\mathrm{EU}$ 加盟国以外の国で販売される場合

第 15 条 Lambrusco のワイン

ワインの表示におけり「Lambrusco」の名称の使用 は, 次の場合には協定発効後 12 ケ月間は認められる。

(a)この名称が伝統的にこの名称でつくられ, 販売 されるワインの種類を示すために使われる場合 であって，

(b)この名称がワインがつくられるブドウ品種を 示すために使われない場合であって，

(c) ワインがオーストラリアを原産とし,

（d）ワインが EU 加盟国以外の国で販売される場合
第 16 条 地理的表示と同じ名称のブドウ品種

表 2 に示す名称の使用は，オーストラリアを原産と するワインの場合であって, ワインが生産されるブド ウの品種を表示するために使われる場合は認められる。 表 2

Alicante Bouchet, Barbera, Carignane, Chardonnay, Orange Muscat, Pinot Chardonnay, Rhine Riesling, Trebbiano

\section{第 4 部 表示}

第 18 条 定義

この部において,「ワイン」とは, オーストラリア で販売され，オーストラリアへ輸入され又はオースト ラリアから輸出されるワインをいう。

第 19 条 複数の国を原産とするワイン

ワインが複数の国で栽培されたブドウからつくられ ている場合は，そのワインの表示に打いて各国を原産 とするワインの割合を示さなければならない。

第 20 条 ブドウ品種

（1）オーストラリアを原産とするワインの表示におけ る品種名の使用は次の機関の少なくとも一つによ って認められたブドウの名前又は同義語でなけれ ばならない。

(a) OIV

（b）植物新品種保護国際同盟（International Union for Protection of New Varieties of Plants)

(c) 国際植物遺伝資源機関 (International Plant Genetic Resources Institute)

（2）オーストラリアを原産とするワインで， 2 以上の 品種からつくられるワインであって, ある品種か らのワインが $850 \mathrm{ml} / \mathrm{L}$ 以上である場合は，その 品種名のみを表示することができる。

（3）オーストラリアを原産とするワインで 2 以上の品 種を表示する場合は,

(a) 品種からのワインの量の割合に応じた順序で品 種名が列挙されなければならない。

（b）表示された品種からのワインの量は, 表示さ 
れていない品種からのワインの量より多くなけ ればならない。

(c) $850 \mathrm{ml} / \mathrm{L}$ 以上は表示された品種からのワインで なければならない。

（4）上記（2）及び（3）の場合の品種からのワインの 量の決定に当たっては，甘味化 (sweetening) 及び酵母など微生物の培養物の量は, $50 \mathrm{ml} / \mathrm{L}$ を 限度として除かれる。

（5）酒精強化ワインにおいて品種からのワインの量の 決定に当たっては，ワインに添加されたグレープ スピリッツ又はブランデーは除いて計算される。

第 21 条 オーストラリアにおける地理的表示の使用

（1）オーストラリアに関連して複数の地理的表示が表 示される場合，登録された地理的表示及び外国の 地域の名称の数は 3 以下でなければならない。

（2）一つの地理的表示を表示する場合で,

（a）オーストラリアに関連した地理的表示を使い,

（b）他の国に関連した地理的表示を使用せず,

（c）外国の地域の名を使用しない，場合は, 地理的表示に関連したオーストラリアの地域又は地 方で栽培されたブドウから得られたワインが $850 \mathrm{ml} / \mathrm{L}$ 以上でなければならない。

（3）2つ又は 3 つの地理的表示を表示する場合で,

（a）少なくとも一つはオーストラリアに関連する地 理的表示で,

（b）外国の地域の名前を使用しない場合は,

ワイン及び表示は次の（4）の要求を満たしていな ければならない。

(4)

(a) 合計でワインの $950 \mathrm{ml} / \mathrm{L}$ 以上が登録された地 理的表示に関連した地域, 地方で栽培されたブ ドウから得られたワインでなければならない。

(b) ワインの $50 \mathrm{ml} / \mathrm{L}$ 以上が各当該地域, 地方から 得られたワインでなければならない。

(c) 登録された地理的表示の表示は, ワインのブド ウの割合に応じた順番で記載されなければなら ない。
（5）ワインの表示が次を使用している場合は, ワイン 及び表示は, 次の（6）の要求事項を満たしてい なければならない。

（a）少なくとも一つがオーストラリアに関連した地 理的表示で,

（b）少なくとも一つが外国の地域名

(6)

(a) 合計でワインの $950 \mathrm{ml} / \mathrm{L}$ 以上が登録された地 理的表示に関連した地域, 地方及び外国の地域 名で特定された地域又は地方で栽培されたブド ウから得られたワインでなければならない。

(b) ワインの $50 \mathrm{ml} / \mathrm{L}$ 以上が各当該地域, 地方から 得られたワインでなければならない。

(c) 登録された地理的表示及び外国の地域の名の表 示は, ワインのブドウの割合に応じた順番で記 載されなければならない。

（7）この規則において,「外国の地域名」とは, ワイ ンに関係した次の表現をいう。

(a) 登録された地理的表示でなく，

（b）産品の原産地である国，地域又は地方を示し た名である。

第 22 条 ヴィンテッジ (Vintages)

(1)

（a）複数の収穫年のブドウを使用したオーストラリ アを原産とするワインで,

（b）これらの収穫年の一つ以上の収穫年を表示す る場合は, ワインの表示に拈いてすべての収穫 年をワイン中のブドウに関連する割合の順序で 示さなければならない。

（2）上記（1）にかかわらず，ある年に収穫されたブ ドウによるワインが $850 \mathrm{ml} / \mathrm{L}$ 以上である場合は, その収穫年のみを表示することができる。

（4）上記（2）の場合において, 酒精強化ワインのブ ドウの量は, ワインに添加されたグレープスピリ ッツ又はブランデーを除いて計算されなければな らない。 


\section{第 5 部 地理的表示決定の条件}

第 24 条 定義

この部において「地域 (region)」とは,

（a）一つ又は複数の小地域（subregion）を含むこ とができ，

（b）土地の単一の広がりであり，それがブドウ栽 培の性質に求いて他と異なりまた同質であり,

（i ）測ることが可能で,（ii）小地域より実質 的 (substantial) でなく,

(c) 年間 500 トン以上の生産があり,

(d) 5ha 以上のヴィンヤードが5つ以上あり,

（e）地域として合理的に認識され得ること。

「小地域 (subregion)」とは,

(a) 地域の一部で,

（b）土地の単一の広がりであり，それがブドウ栽 培の性質において他と異なりまた同質であり,

実質的（substantial）であり，

(c) 年間 500 トン以上の生産があり,

(d) 5ha 以上のヴィンヤードが 5 つ以上あり ,

(e) 小地域として合理的に認識され得ること。

第 25 条 地理的表示決定の基準

委員会は，次の基準を考慮しなければならない。

（a）地域又は小地域の定義に合致しているかどうか。

（b）政府の記録，新聞，文献，書籍，地図などで 確認された当該地域の建設及び発展の歴史

（c）河川，等高線，その他の地形上の特徵

（d）道路，鉄道，町建物など建設されたものの 存在

(e) 法第 $40 R$ 条の下で委員会に適用される地域の 境界

(f) 当該地域に関連した ordinance survey map

（g）当該地域に関連した地方政府の境界

（h）次のものを含む当該地域を示す用語や表現の 存在

(i ）用語や表現の歴史

（ii）当該地域の以外の小売業者に当該用語や表 現がどのくらい知られているか。

（iii）当該地域又はその他で当該用語や表現が伝 統的にどの程度使われていたか。 （i）提案された地理的表示の次の事項についての同 一性と離反性の程度

(i ) 当該地域の地学上の形成

(ii) 気温, 気圧, 湿度, 降雨, 日照時間などに 関する当該地域の気候に関する程度

（iii）ある特定のブドウ品種の収穫の始まる時期 が他の地域の同じ品種のブドウの収穫の始ま る時期と同じかどうか。

（iv）当該地域の全体が同一の流水域内にあるか どうか。

( v ）灌溉施設からの取水の可能性

（vi）当該地域の標高

（vii）連邦，州，又は市町村から提案されている 開発計画があるかどうか。

（viii）当該地域内に伝統的な地域区分があるかど うか。

（ix）当該地域に扔けるブドウ栽培とワイン生産 の歴史

VI オーストラリア・ニュージーランド食品基準

(Australia New Zealand Food Standards Code 1991）のワイン関係部分の概訳

一ワインの義務表示及びワインの製造基準一 輸入ワインにも適用される。

\section{1 義務表示}

食品基準 第 1.2.2，第 1.2.3，第 1.2.5，第 2.7.1 など 注：ワイン以外の食品・飲料にも適用される基準で ある。

産品の種類の名（第 1.2.2）

産品の種類の名を表示しなければならない。

注：「ワイン」と表示する場合は，ワイン法及び基準 で定められた定義に合致していなければならず，水や 色素を添加したワインは,「ワインをべースとした飲 料（“Wine Based Beverage”) などと表示しなければ ならない。

供給業者の名前と住所（第 1.2.2）

供給業者の名前と住所を表示しなければならない。 
原産国（第 1.2.2）

食品の原産国を表示しなければならない。

注：「Wine of Australia」又は「Australian Wine」 は地理的表示であり，原産国表示ではない。ま た, 輸入ワインとのブレンドのワインはワイン 法第 19 条に従い,「オーストラリア $90 \%$, ニ

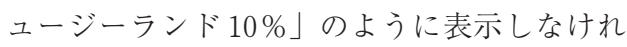
ばならない。

ロット番号（第 1.2.2）

ロット番号を表示しなければならない。

注：ロット番号は食品安全確保のために義務付けら れている。事故が生じた場合同一のロット番号 のものはすべて回収しなければならない。番号 は「L9330」や「330th day of 1999」のように つけられる。

\section{アレルギー物質（第 1.2.3）}

すべての食品（ワインを含む）についてグルテン及 びそれを含む物質，甲殼類及びそれを含む物質，卵及 び卵製品，乳及び乳製品，ナッッ，ごまの種，落花生， 大豆及びその製品, $10 \mathrm{mg} / \mathrm{kg}$ 以上含まれる二酸化硫黄, ロイヤルゼリー, 蜂花粉並びにプロポリスが含まれる 場合は，それが含まれることを開示 (declaration) し なければならない。

注：ワインについて清澄のため卵白を使った場合は, 「卵」を表示しなければならない。

賞味期限（第 1.2.5）

使用期限が 2 年未満の場合は, 賞味期限を表示しな ければならない。

注：ワインの場合は, びん以外の容器を使用してい るワインについて適用となる可能性がある。

アルコール分（第 2.7.1）

容量で $1.15 \%$ 超えるアルコールを含む飲料は, $\mathrm{mL} / 100 \mathrm{~g}, \mathrm{~mL} / 100 \mathrm{~mL}$ または容量パーセント表示でア ルコール含量を表示しなければならない。誤差の範囲 はワイン及びスパークリングワインについては 1.5 容 量％, 酒精強化ワインについては 0.5 容量％である。 基準飲酒量（standard drink labeling）（第 2.7.1）

基準飲酒量（standard drink）とは $10 \mathrm{~g}$ のエタノー ルを基準とした飲料の総量をいう。0.5\%を超えるアル コール分を有する飲料には, 基準飲酒量を表示しなけ ればならない。

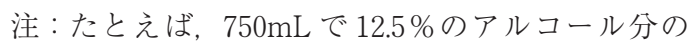
ワインにおける基準飲酒量は, 約 7.4

容器容量 $(\mathrm{L}) \times$ ×ルコール分 $(\mathrm{mL} / 100 \mathrm{~mL})$ $\times 0.79$

容量（第 4.5.1）

ワインの容量を容器の大きさ（高さ）に応じて次の 高さの文字の大きさで表示しなければならない。

\begin{tabular}{|c|c|}
\hline 容器の高さ & 最小の文字の高さ \\
\hline$<120 \mathrm{~mm}$ & $2.0 \mathrm{~mm}$ \\
\hline $120-<230 \mathrm{~mm}$ & $2.5 \mathrm{~mm}$ \\
\hline $230-<360 \mathrm{~mm}$ & $3.3 \mathrm{~mm}$ (standard $750 \mathrm{~mL}$ bottle) \\
\hline$>360 \mathrm{~mm}$ & $4.8 \mathrm{~mm}$ \\
\hline
\end{tabular}

注：ラベルにおける表示は，一般には，字の大きさ は $3 \mathrm{~mm}$ 以上，パッケージが小さい場合は $1.5 \mathrm{~mm}$ 以上でなければならない（第 1.2.9）。

注：任意表示事項及び一般表示事項は次のようであ る。

任意表示

バーコード, ブレンドの詳細, 地理的表示, 健康 上の警告, ブドウ品種, ヴィンテッジなど

一般表示

著作権, 受賞, 環境表示, 健康表示, 受賞メダル, 商標など

\section{2 ワイン及びワイン産品 \\ 食品基準 第 2.7 .4}

\section{第 1 節 定義}

この基準において, ワインとは, 新鮮なブドウを完 全にまたは部分的に発酵させたものであって, 単独で ブドウから得られた産品及びこれらを混合した産品を いう。

ワイン製品（wine product）とは，この基準で定義 されたワインを $1 \mathrm{~L}$ 中 $700 \mathrm{ml}$ 以上含み, 処理され, 加 工され, 調整され, または, ワインではないほかの食 
品と混合されたものをいう。

\section{第 2 節 ワイン製造中に加えることのできる食品}

以下の食品は，ワイン製造中に加えることができる

(a) ブドウ果汁及びブドウ果汁製品

(b) 糖類

(c) ブランデーまたはその他の蒸留酒

(d) 水：許可された食品添加物もしくは加工助剂 とともに使用することが必要な場合

\section{3 ワイン製造基準}

食品基準 第 4.5.1（オーストラリア限定）

\section{第 1 節 定義}

「ブランデー」とは, この製造基準の別表の仕様に 従い, ブランデーが一般に有する味, 香り及びその他 の特徵を保証する方法を用いて, ワインを蒸留して得 られた蒸留酒をいう。

「酒精強化ワイン」とは，ワインにグレープスピリ ッッ, ブランデー, あるいはその両方を添加したワイ ン産品をいう。

「グレープスピリッッ」とは, ワイン, ワインの副 産物あるいは乾燥ブドウのもろみを発酵させた酒類を 蒸留して得られる蒸留酒であって, メ夕ノールが, 20 ${ }^{\circ} \mathrm{C}$ に扔いて純エタノール $1 \mathrm{~L}$ 当たり $3 \mathrm{~g}$ を超えない蒸 留酒をいう。

「スパークリングワイン」とは, 含有する糖分を完 全にあるいは部分的に発酵させて, 二酸化炭素を付加 したワイン産品をいう。

「ワイン」とは, 新鮮なブドウを完全にあるいは部 分的に発酵させたものであって, 単独でブドウから得 られた産品及びこれらを混合した産品をいう。

\section{第 2 節 適用}

この製造基準は, オーストラリアで生産されるワイ ンにのみ適用する。

注：ニュージーランドには適用されないという意味 であり，国際協定に別の規定がある場合を除き， 原則として輸入ワインにも適用される。

\section{第 3 節 生産に用いる物品}

（1）この節の表に示された物質は，第 5 節で課せられ
た制限範囲内で，ワイン，スパークリングワイン 及び酒精強化ワインに使用できる。

（2）この節において「ミステル (mistelle)」とは, 新 鮮なブドウから調整されたブドウのマストか果汁 に, 発酵防止のためグレープスピリッッを添加し， $20^{\circ} \mathrm{C}$ に拈いて $120 \mathrm{~mL} / \mathrm{L}$ から $150 \mathrm{~mL} / \mathrm{L}$ のエノ ールを含むよう調整したものをいう。

第 3 節 表

\begin{tabular}{|l|}
\hline \multicolumn{1}{|c|}{ 添加物 } \\
\hline アスコルビン酸 \\
炭酸ガス \\
クエン酸 \\
二炭酸ジメチル（Dimethyl dicarbonate, DMDC） \\
エリソルビン酸 \\
濃縮ブドウ果汁を含むブドウ果汁 \\
ブドウ果皮抽出物 \\
アラビアガム \\
乳酸 \\
リンゴ酸 \\
メタ酒石酸 \\
ミステル \\
ソルビン酸カリウム \\
亜硫酸カリウム類 \\
ソルビン酸 \\
二酸化硫黄 \\
タンニン \\
酒石酸 \\
酵母マンノプロテイン
\end{tabular}

\section{第 4 節 加工助剤}

（1）この節の表に示された物質は，第 5 節で課せられ る制限範囲内で, ワイン，スパークリングワイン 及び酒精強化ワインに使用できる。

（2）この節において，「微生物の培養物（cultures of micro-organism)」とは, チアミン塩酸塩, ピリ ドキシン, パントテン酸, ビオチン, イノシトー ルのいずれかまたは複数の添加の有無にかかわら ずワイン製造に使用される酵母（酵母細胞壁を含 む）やバクテリアをいう。

(3) 塩化チアミン, チアミン塩酸塩は, ワイン, スパ ークリングワイン及び酒精強化ワインの微生物の 増殖促進の目的でのみ添加することができる。 
第 4 節 表

\begin{tabular}{|c|}
\hline 加工助㧩 \\
\hline 活性炭 \\
\hline 寒天 \\
\hline アルギン酸カルシウム及びカリウム \\
\hline リン酸アンモニウム類 \\
\hline アルゴン \\
\hline ベントナイト \\
\hline 炭酸カルシウム \\
\hline 酒石酸カルシウム \\
\hline 二酸化炭素 \\
\hline セルロース \\
\hline コラーゲン \\
\hline 硫酸銅 \\
\hline 微生物の培養物 \\
\hline クエン酸銅 \\
\hline ケイソウ土 \\
\hline $\begin{array}{l}\text { ジメチルポリシロキサン（Dimethylpolysiloxane, シリコ } \\
\text { ーン樹脂） }\end{array}$ \\
\hline 卵白 \\
\hline 酵素類 \\
\hline ゼラチン \\
\hline 過酸化水素 \\
\hline イオン交換樹脂 \\
\hline アイシングラス \\
\hline リゾチーム \\
\hline 乳及び乳製品 \\
\hline 窒素 \\
\hline オーク \\
\hline 酸素 \\
\hline パーライト \\
\hline フィチン類 \\
\hline $\begin{array}{l}\text { 植物性たんぱく質, 食品製造基準 } 1.3 .3 \text { 第 } 3 \text { 節（a）にお } \\
\text { いて加工助郕とし認められているもの }\end{array}$ \\
\hline ポリビニルポリピロリドン \\
\hline 孷酸カリウム \\
\hline フェロシアン化カリウム \\
\hline 炭酸水素カリウム \\
\hline 酒石酸水素カリウム \\
\hline 二酸化ケイ素 \\
\hline 塩化チアミン \\
\hline チアミン塩酸塩 \\
\hline
\end{tabular}

\section{第 5 節 組成}

（1）ワイン及びスパークリングワインは，20ㄷ におい て $80 \mathrm{~mL} / \mathrm{L}$ 以上のエタノールを含まなければな らない。

（2）（1）であっても，ワインは添加したエタノールを 含んではならない。

（3）酒精強化ワインは， $20^{\circ} \mathrm{C}$ に扔いて $150 \mathrm{~mL} / \mathrm{L}$ 以上 $220 \mathrm{~mL} / \mathrm{L}$ 以下のエタノールを含まなければなら ない

（4）ワイン，スパークリングワイン及び酒精強化ワイ ンは以下のメタノールを含んではならない。

(a) 白ワイン, 白のスパークリングワインにおいて

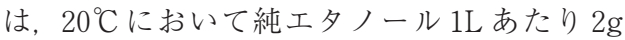
を超えるメタノール

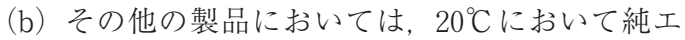
タノール1Lあたり $3 \mathrm{~g}$ を超えるメタノール

（5）ワイン，スパークリングワイン及び酒精強化ワイ ンに扔いては，下項の数值以下でなければならな い

(a) 糖分が $35 \mathrm{~g} / \mathrm{L}$ 未満の製品における総二酸化硫 黄は $250 \mathrm{mg} / \mathrm{L}$ ，その他の製品の場合は $300 \mathrm{mg} /$ L

(b) ソルビン酸, ソルビン酸カリウムは, ソルビ ン酸として $200 \mathrm{mg} / \mathrm{L}$

(c) 可溶性塩化物は, 塩化ナトリウムとして $1 \mathrm{~g} / \mathrm{L}$

(d) 可溶性硫酸塩は, 硫酸カリウムとして $2 \mathrm{~g} / \mathrm{L}$

(e) 可溶性リン酸塩は,リンとして $400 \mathrm{mg} / \mathrm{L}$

(f) 二酸化硫黄を除く揮発酸度は, 酢酸として $1.5 \mathrm{~g} / \mathrm{L}$

（g）シアン化物またはシアン化物錯体は，シアン 化水素として $0.1 \mathrm{mg} / \mathrm{L}$

（h）二炭酸ジメチルの添加量は $200 \mathrm{mg} / \mathrm{L}$

（6）フェロシアン化カリウムが，ワイン，スパークリ ングワイン, 酒精強化ワインの製造に加工助剤と して使用された場合，最終製品には残余の鉄が含 まれる。

（7）ワイン，スパークリングワイン及び酒精強化ワイ ンには，第 3 節または第 4 節に指定された物質に 伴って必要とされる水, あるいはワイン醸造工程 に付随する水でかつワイン中の水の存在が優良製 造規範（GMP）に適合している場合に，1Lあた り $70 \mathrm{~mL}$ を超えない範囲で水を含むことがある。 
（8）この節では，（a）第 3 節の表における食品添加物 リスト（b）第 4 節の表に扮ける加工助剤につ いて, これ以外に最大許容量を規定するものでは ない。食品添加物及び加工助剤の使用は優良製造 規範（GMP）の条件に従わなければならない。

\section{第 6 節 スパークリングワイン}

（1）第 3 節, 第 4 節で認可された物品に加え, スパー クリングワインは次のものを含んでもよい。

(a) グレープスピリッッ

(b) ブランデー

(c) 糖類

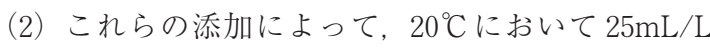
を超えるエタノールの増加がないようにしなけれ ばならない。

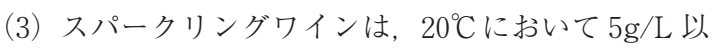
上の二酸化炭素を含まなければならない。

\section{第 7 節 酒精強化ワイン}

第 3 節及び第 4 節で認可された物品に加え, 酒精強 化ワインはカラメルを含んでもよい。

\section{別表 この製造基準のための仕様}

(1) ブランデー

(a) 木製容器で 2 年以上熟成させなければならない

(b) $20^{\circ} \mathrm{C}$ に拈けるエタノールが $830 \mathrm{~mL} / \mathrm{L}$ 以下とな るよう蒸留されたものであって, $250 \mathrm{ml} / \mathrm{L}$ 以上 のエタノールを含まなければならない。 （c）次のものを含んでもよい

(i) 水

(ii ) カラメル

(iii) 糖類

（iv）ブドウ果汁及び濃縮ブドウ果汁

( v ) ワイン

(vi）プルーン果汁

（vii）蜂蜜

(viii) 香料

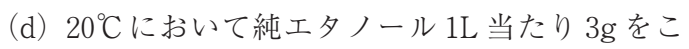
えるメタノールを含んではならない。

\section{注 以上の法令の概訳を読むに当たっての注意事項}

この概訳は, 法令の条文をそのまま訳したものでな く, 条文の要点の訳である。従って, 重要でない部分 は訳していない場合があり, また, 表現も正確な訳と いうより分かりやすくしている。また, 各条文全部に ついて概訳をしたものでなく，訳さなかった条もある。 条文番号やパラグラフ番号に欠落がある場合は，その 番号の条文を訳していないということである。この資 料では条文番号は原文と同じにしてあるので正確な条 文の内容を知る必要がある場合は，原文を参照してい ただきたい。

なお,「注」は訳者の注である。

この資料の作成に当たっては, 国税庁酒類国際技術 情報分析官 宇都宮 仁氏に, 特にワインの製造基準 に関しご協力いただいた。

〈東京大学農学生命科学研究科非常勤講師〉 
オーストラリアの地理的表示名

2011 年現在

\begin{tabular}{|c|c|c|}
\hline 州, 地方 & 地域 & 小地域 \\
\hline \multicolumn{3}{|l|}{ Australia/Australian } \\
\hline \multicolumn{3}{|l|}{ South Australia } \\
\hline $\begin{array}{l}\text { Adelaide } \\
\text { Barossa }\end{array}$ & $\begin{array}{l}\text { Barossa Valley } \\
\text { Eden Valley }\end{array}$ & High Eden \\
\hline $\begin{array}{l}\text { Far North } \\
\text { Fleurieu }\end{array}$ & \begin{tabular}{|l} 
Southern Flinders Ranges \\
Currency Creek \\
Kangaroo Island \\
Langhorne Creek \\
McLaren Vale \\
Southern Fleurieu
\end{tabular} & \\
\hline Limestone Coast & $\begin{array}{l}\text { Coonawarra } \\
\text { Mount Benson } \\
\text { Mount Gambier } \\
\text { Padthaway } \\
\text { Robe } \\
\text { Wrattonbully }\end{array}$ & \\
\hline Lower Murray & Riverland & \\
\hline Mount Lofty Ranges & $\begin{array}{l}\text { Adelaide Hills } \\
\text { Adelaide Plains } \\
\text { Clare Valley }\end{array}$ & $\begin{array}{l}\text { Lenswood } \\
\text { Picadilly Valley }\end{array}$ \\
\hline \multicolumn{3}{|l|}{ The Peninsulas } \\
\hline \multicolumn{3}{|l|}{ New South Wales } \\
\hline Big Rivers & $\begin{array}{l}\text { Murray Darling } \\
\text { Swan Hill } \\
\text { Perricoota } \\
\text { Riverina }\end{array}$ & \\
\hline Central Ranges & $\begin{array}{l}\text { Cowra } \\
\text { Mudgee } \\
\text { Orange }\end{array}$ & \\
\hline Hunter Valley & Hunter & $\begin{array}{l}\text { Broke Fordwich } \\
\text { Pokolbin } \\
\text { Upper Hunter Valley }\end{array}$ \\
\hline Northern Rivers & Hasting Rivers & \\
\hline Northern Slopes & New England Australia & \\
\hline South Coast & $\begin{array}{l}\text { Shoalheaven Coast } \\
\text { Southern highlands }\end{array}$ & \\
\hline Southern New South Wales & $\begin{array}{l}\text { Canberra District } \\
\text { Gundagai } \\
\text { Hilltops } \\
\text { Tumbarumba } \\
\end{array}$ & \\
\hline \multicolumn{3}{|l|}{ Western Plains } \\
\hline Victoria & & \\
\hline
\end{tabular}




\begin{tabular}{|c|c|c|}
\hline Central Victoria & $\begin{array}{l}\text { Bendigo } \\
\text { Goulburn Valley } \\
\text { Heathcote } \\
\text { Strathbogie Ranges } \\
\text { Upper Goulburn }\end{array}$ & Nagambie Lakes \\
\hline \multicolumn{3}{|l|}{ Gippsland } \\
\hline North East Victoria & $\begin{array}{l}\text { Alpine Valleys } \\
\text { Beechworth } \\
\text { Glenrowan } \\
\text { King Valley } \\
\text { Rutherglen }\end{array}$ & \\
\hline North West Victoria & $\begin{array}{l}\text { Murray Darling } \\
\text { Swan Hill }\end{array}$ & \\
\hline Port phillip & $\begin{array}{l}\text { Geelong } \\
\text { Macedon Ranges } \\
\text { Mornington peninsula } \\
\text { Sunbury } \\
\text { Yarra Valley }\end{array}$ & \\
\hline Western Victoria & $\begin{array}{l}\text { Grampians } \\
\text { Henty } \\
\text { Pyrenees }\end{array}$ & Great Western \\
\hline \multicolumn{3}{|l|}{ Western Australia } \\
\hline \multicolumn{3}{|l|}{ Central Western Australia } \\
\hline \multicolumn{3}{|l|}{$\begin{array}{l}\text { Eastern plains, Inland and } \\
\text { North of Western Australia }\end{array}$} \\
\hline Greater Perth & $\begin{array}{l}\text { Peel } \\
\text { Perth Hills } \\
\text { Swan District }\end{array}$ & Swan Valley \\
\hline South West Australia & $\begin{array}{l}\text { Black Wood Valley } \\
\text { Geographe } \\
\text { Great Southern } \\
\text { Manjimup } \\
\text { Margaret River } \\
\text { Pemberton }\end{array}$ & $\begin{array}{l}\text { Albany } \\
\text { Denmark } \\
\text { Frankland River } \\
\text { Mount Barker } \\
\text { Porongurup }\end{array}$ \\
\hline \multicolumn{3}{|l|}{$\begin{array}{l}\text { West Australia South East } \\
\text { Coastal }\end{array}$} \\
\hline \multicolumn{3}{|l|}{ Queens Land } \\
\hline & $\begin{array}{l}\text { Granite Belt } \\
\text { South Burnett }\end{array}$ & \\
\hline \multicolumn{3}{|l|}{ Tasmania } \\
\hline \multicolumn{3}{|l|}{ Northern Territory } \\
\hline Australian Capital Territory & & \\
\hline
\end{tabular}

